\title{
E-Commerce in Lithuania
}

\author{
Arnoldina Pabedinskaite, Mykolas Romeris University
}

\begin{abstract}
A successful business development cannot be currently imagined without the active use of cutting-edge information technologies and the Internet. Nowadays, technologies offer a wide range of opportunities for entering the international market and expanding the existing one by various methods.

In 2011, Lithuania ranked $22^{\text {nd }}$ by the volume of e-commerce among the EU member states with $11 \%$ of individuals purchasing online compared to the total number of the population, while in the $\mathrm{EU}$ the number of e-commerce users accounts for $34 \%$ on average. Therefore, although the number of e-commerce users is continuously growing, the penetration of ecommerce in Lithuania is far below the $\mathrm{EU}$ average.

The aim of this article is to perform an analysis of the development of e-commerce in Lithuania and to identify some characteristics of e-consumers' behaviour.

Research methods: comparative analysis of scientific literature, statistical data processing methods.
\end{abstract}

Keywords: e-commerce, consumers' behaviour

\section{INTRODUCTION}

The fast development of information technologies, the increasing use of the Internet in various areas of activities of enterprises have a profound impact on both the sales of products and services over the Internet, and the shift of traditional marketing to an electronic medium, thus ensuring low costs and gaining competitive advantages. At present, successful business development cannot be imagined without the active use of cutting-edge information technologies and the Internet. Nowadays, technologies offer a wide range of opportunities for entering the international market and expanding the existing one by various methods. The information technologies have enabled and, in some cases, forced organizations to review their business models, to transform their internal processes, to be able to take advantage of electronic business methods and to create supply chains which will reduce time and money costs $[1 ; 2 ; 6 ; 8 ; 11 ; 19]$.

The Internet and digital media have also transformed the process of traditional marketing. Thus, consumers are able to access information about various products, services, prices quickly, easily, and at any time of the day, and organizations and enterprises have been provided with a possibility of entering new electronic markets, offering a wider variety of products and services, introducing new means of communication and competing under more promising conditions. Online marketing, undoubtedly, opens up a host of new opportunities and provides advantages to enterprises, because it allows them to establish an interactive connection and to maintain long-term relations with consumers by engaging them in the life of an organisation and, thus, gaining the consumer's trust and loyalty. Online marketing allows effectively reaching target customers, developing a better understanding of their needs, providing them with customerspecific offers and obtaining feedback. Moreover, enterprises are provided with a possibility to communicate with their target audiences in different ways at the same time, to reach target groups of consumers in any place around the world where there is access to the Internet.

Literary sources provide different definitions of electronic business. The concepts of electronic commerce and electronic business are particularly intertwined; however, a majority of authors indicate that electronic commerce is only partially related to electronic business $[7 ; 9 ; 20 ; 21 ; 22 ; 28]$. The Lithuanian Concept of e-Business defines it as performance of business operations and organisation of activities of an enterprise through the use of information technologies in data transmission networks. This includes various activities aiming at earning profit - commerce, marketing, teleservices, telemedicine, distance learning, distance work, banking and other activities pursued over the Internet. E-business covers not only ordinary business operations, but also new business methods, which are possible only in a virtual environment.

The models used in electronic business are primarily classified by participants: business-to-consumer (B2C), business-to-business (B2B), consumer-to-business (C2B), consumer-to-consumer (C2C), peer-to-peer (P2P), government-to-business (G2B), government-to-consumer $(\mathrm{G} 2 \mathrm{C})$, business-to-employee (B2E), as well as governmentto-government $(\mathrm{G} 2 \mathrm{G})[7 ; 16 ; 20 ; 21 ; 22 ; 28]$. The main ebusiness models connect consumers, business and government institutions. Many authors note the advantages of electronic business and considerable opportunities for the use of electronic business methods in small-sized enterprises [6; 9; $21 ; 23 ; 24 ; 28 ; 29]$, for example: reduction of costs, opportunities of international trade, improvement of the supply chain, new co-operation possibilities, new business models, new markets, uninterrupted work, improvement of communications, improvement of search for information, promotion of sales and new opportunities for marketing, improvement of a company's image and relations with customers.

E-commerce covers all types of relations linked with conclusion of international and national transactions: procurement, sales, supply, making orders, advertising, consulting, various agreements and forms of business-related co-operation. The main types of e-commerce are e-shops, online announcements, online auctions, e-banking, eintermediation services. Over the Internet, everything is purchased and sold:

o products: computers, software, clothing, books, audio and video records, food products, beverages, sports goods, mobile phones, perfumes and other items that can be imagined;

o entertainment: games, lotteries, etc.;

o services - travels, online trading venues, advertisements, announcements, job search and job offers, etc.

Internet and information technologies enable businesses to obtain all dimensions of values - to help reduce costs involved in the delivery of digital products and customer support. Web 
$2013 / 24$

sites are a major source of data related to consumer buying habits. Such data provide the possibility of developing a more intimate relationship with customers. In their efforts to obtain business values, enterprises often follow a phased life-cycle pattern in establishing web-sites:

1. Being on the Internet. Internet site creation, first, provides information about a company, products and services to its customers.

2. Interaction. Internet use for interaction with customers: e-mails, interviews and feedback.

3. Transactions. Internet use for transactions with customers, control and maintenance.

4. Co-operation (collaboration). Use of the Internet for inter-organizational activity, which can be available and useful for the company and its partners.

The use of ICT in all types of business or public activities creates competitive advantages, expands possibilities to act faster and execute business processes more efficiently.

Development of e-commerce is determined by a number of various factors. First and foremost, the extent of e-commerce in a country is affected by technical possibilities (Internet penetration), as well as by the computer literacy of the population. The virtual European market is dominated by the countries of Western and Northern Europe. Sweden, Norway, Denmark, Finland and Iceland have the highest Internet penetration rate. Moreover, it is possible to presuppose that climate conditions have a certain influence on the development of e-commerce in these countries. Meanwhile, in countries with a warmer climate traditional trade is more popular. Besides the factors related to the ICT development level, another group should be taken into consideration when discussing e-commerce, which is cultural factors. Culture as a system of values and valid social norms has a direct and indirect impact on formation of the consumer attitude and choice of social communication ways. One of the cultural dimensions determining the spreading of e-commerce is the degree of individualism on the individualism/collectivism scale. In an individualistic culture, a person's behaviour and values are determined by a person's choice, goals and motivation. Therefore, members of such a society accept innovations more easily, have more self-confidence and perceive less risk in relation with strangers. As a result of such characteristics, these individuals have positive attitude towards purchasing online.

Although the number of e-commerce users in Lithuania is continuously growing, the penetration of e-commerce is far below the EU average.

The aim of this article is to perform an analysis of the development of e-commerce in Lithuania and to identify some characteristics of e-consumers' behaviour.

Research methods: comparative analysis of scientific literature, statistical data processing methods.

\section{II.E-COMMERCE IN THE EU MEMBER STATES AND IN LITHUANIA}

In 2011, the average Internet penetration in the EU-27, i.e., the ratio of the number of Internet users to the number of the population, accounted for as much as $70.3 \%$, and in Lithuania this ratio was equal to $61 \%$. According to this indicator,
Lithuania ranks $21^{\text {st }}$ among the $27 \mathrm{EU}$ member states (Latvia is $15^{\text {th }}$ with the penetration of $69.9 \%$ ) (Eurostat data).

The share of individuals purchasing over the Internet in the EU-27 accounts for $34 \%$ of the population. In 2011, most online purchases were made by residents of the United Kingdom (64\%), Denmark (57\%), Germany (54\%), whereas the residents of Romania (4\%) and Bulgaria (5\%) purchased the least. Lithuania (11\%) was in the same group with Greece, Italy, Latvia, Portugal and Hungary, where e-purchases involved $8-13 \%$ of the population (Lithuania ranks $22^{\text {nd }}$ ). Compared to 2010, Lithuania has moved from the $25^{\text {th }}$ place leaving behind Italy, Latvia and Portugal (this indicator for all three countries is equal to $10 \%$ ).

The behaviour of e-consumers and key factors influencing the decision to purchase online are analysed by many authors $[2 ; 3 ; 4 ; 5 ; 10 ; 12 ; 13 ; 14 ; 17 ; 18 ; 27]$.

The principal reasons for using e-commerce are an opportunity to purchase $24 / 7$, a lower price, time savings and a larger variety of products than in traditional commerce [10; $12 ; 14 ; 26]$.

The largest impact on the decision not to purchase online is exerted by several factors: the absence of the possibility to touch products, the group of insecurity factors (insecure payments, unwillingness to provide personal data over the Internet, mere distrust), delivery problems and price $[10 ; 12$; $14 ; 16 ; 26]$.

As a result, individuals are inclined to purchase mostly the items, which it is not necessary to touch (e.g., tickets, books, CD/DVD) or the products that are well-known, for instance, perfumes, and cosmetics.

The most important factors influencing the level of development of e-commerce in a country are internet penetration and computer literacy of population. According to data of 2011, 61\% of Lithuanian residents aged 16-74 used the Internet and over a half (55.8\%) of households had a computer with Internet access [8]. In respect of the use of the Internet, individuals aged 16-24 were the most active users $(96.3 \%)$, followed by the 25-34 age group (88.5\%). In terms of ecommerce, the most active users were individuals aged 25-34 (33.2\%), followed by the individuals aged 16-24 (24.6\%). Representatives of the 35-44 age group ranked third by the use of the Internet (71.8\%) and e-commerce services (18.5\%). A majority of those using computers and having the Internet access were concentrated around the three largest cities of Lithuania, namely, in Vilnius (65\%), Kaunas (59.3\%) and Klaipèda (58.9\%) regions [30].

Meanwhile, the individuals using computers accounted for $64 \%$ of all individuals aged 16-74 (in 2010, 60\%) [30]. Among elderly individuals (aged 65-74), only 12\% used computers in 2011, whereas $85 \%$ of individuals in this age group had never used it. Therefore, a majority of individuals using computers were young people.

The conclusion that elderly people in Lithuania lack computer literacy skills has led to establishment of the association "Window to the Future", whose mission is to promote the use of the Internet in Lithuania, thus, improving the standard of living and enhancing the country's competitiveness in Europe and worldwide. The activities of the alliance "Window to the Future" are carried out in three directions: 
- by establishing public access to the Internet across broad layers of society,

- by teaching the public how to use computers and the Internet,

- by encouraging the public to use electronic services.

The majority of individuals, who used a computer in 2011, used it daily $(75 \%)$, one-fifth $(21 \%)$ used it at least weekly, if not daily. Therefore, $96 \%$ of Internet users, or $61 \%$ of all residents in the country aged 16-74, used the Internet regularly (at least once a week). $89 \%$ of individuals read or downloaded news, newspapers and magazines online, $86 \%$ searched for information about products or services, $81 \%$ of Internet users used e-mail.

In $2011,54.7 \%$ of Lithuanian residents aged 16-74 searched the web for information about products and services, which shows the potential of e-commerce development in the country and is more than twice as much as in 2005 (Fig. 1). $41.1 \%$ of individuals in this group used e-banking services, $27.9 \%$ - public e-services.

In the business sector in $2011,98.1 \%$ of enterprises used the Internet, $67.7 \%$ of enterprises had a website or a webpage. The majority of the enterprises used information technologies in communicating with state institutions (98\%) and banks (93\%). However, only $33.2 \%$ of enterprises purchased

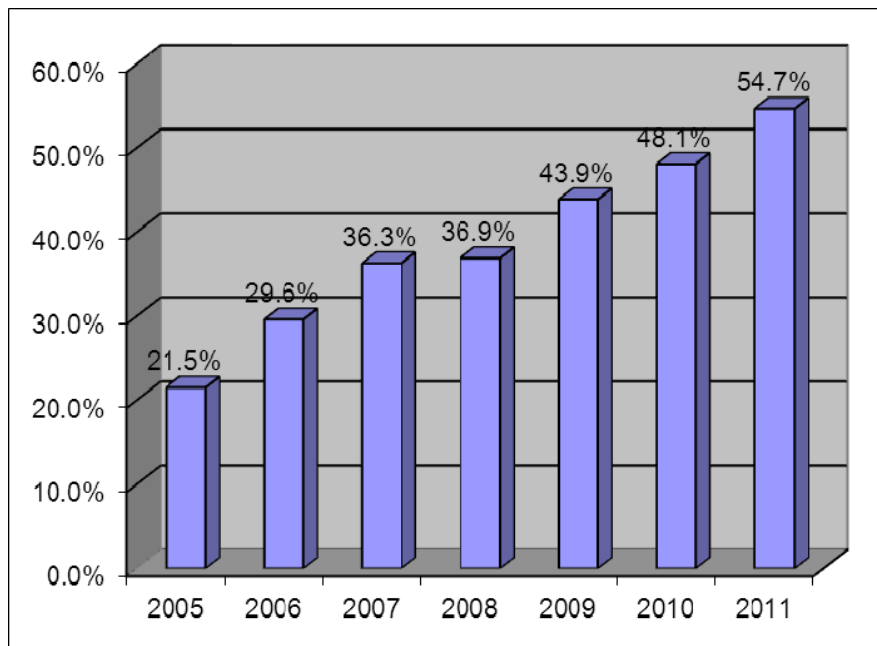

Fig. 1. Share of Lithuanian residents aged 16-74, who searched the web for information about products and services in 2011.

products/services online, and even smaller number of companies $(24.7 \%)$ sold products/services in 2011 . It may be claimed that enterprises still make insufficient use of the possibilities offered by the Internet in the area of commerce, although the number of enterprises using the Internet for the sale/purchasing of products and services is steadily growing (Fig. 2). To sum up, it may be claimed that the volume of ecommerce in Lithuania still lags behind the existing technical possibilities. Thus, the Internet penetration rate accounts for $61 \%$ of the population, meanwhile the number of individuals purchasing over the Internet amounts merely to $11 \%$ of the total number of the population.

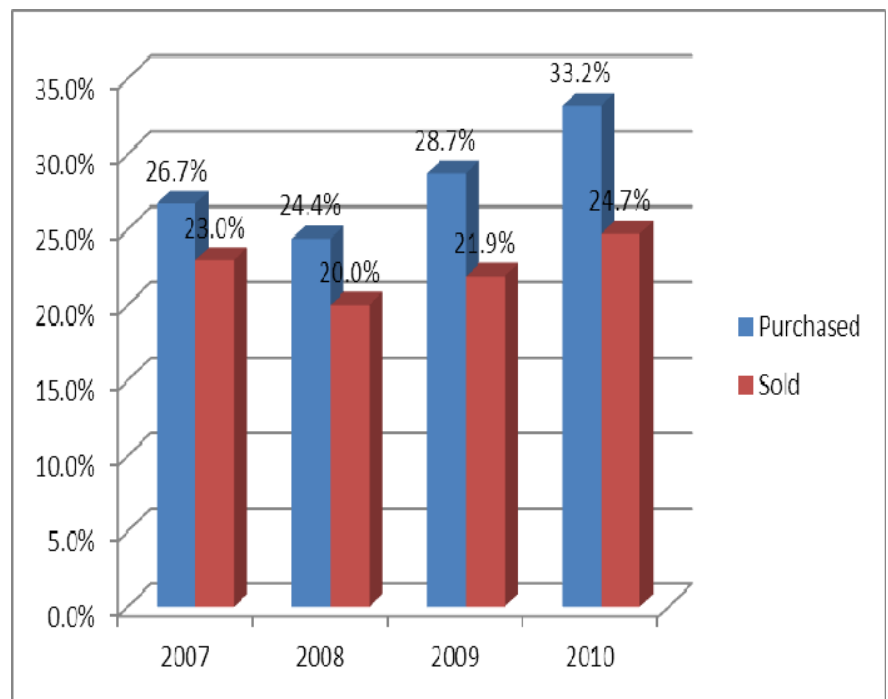

Fig. 2. Changes in the percentage of enterprises using the Internet for the purpose of selling and purchasing products/services over the years 2007 2010 .

A majority of businesses still make insufficient use of the opportunities of e-commerce - only one third of such enterprises make use of this form of commerce. Undoubtedly, the development of e-commerce is a complex process affected by a number of factors, including the level of income of the population and the country's cultural characteristics. Moreover, this development is uneven in different age groups; hence, it is expedient to examine this process and to analyse its different layers.

\section{ANALYSIS OF RESUlTS OF THE CONSUMER RESEARCH}

The aim of the survey is to identify consumers' attitudes towards non-traditional ways of purchasing and the type of products that are most popular and desired. The survey was performed using the Lithuanian web portal for surveys (www.apklausa.lt), sample size was 187 [25]. The results of the survey are the following: $94 \%$ of the respondents use the Internet daily and only $3 \%$ of the respondents use the Internet several times per month. A majority of the respondents $(59 \%)$ belong to the 25-30 age group. This is the main segment of actively working individuals, who earn income and regularly use the Internet. The age of almost all respondents (95\%) was below 45 . A majority of the respondents $(63 \%)$ have higher education, one fifth of the respondents have just secondary education. $53 \%$ of respondents earn moderate income, i.e., LTL 1501-3000. A slightly more than one fourth of the respondents earn up to LTL 1500 . It is possible to claim that individuals with low or moderate income search for ways of saving money, in this case lower prices, and hence purchase in e-shops.

To sum up, it may be claimed that a typical respondent, who replied to questions of the questionnaire, is aged 25-30, has a high school diploma and earns from LTL 1501 up to LTL 3000, uses the Internet daily and purchases online 6-7 times per year on average.

One of the key questions asked by beginners in e-commerce business is about the types of products that are most often purchased over the Internet. The survey has revealed a considerable variety of products purchased online (Fig. 3). 
The most popular products are tickets to entertainment events, travel tickets and discount vouchers, that is, the products that it is not necessary to touch and view in real terms. Clothing, underwear and footwear are also quite popular goods. However, it is a rather difficult task to choose a product of this type and the appropriate size of the product over the Internet. These results of the survey do not fully coincide with the statistical data presented at the beginning of the Section and show that clothing and footwear rank second among most popular purchases online. It looks like official statistics still does not recognize such a new 'product' as various discount vouchers, which are used by e-shops to attract new customers and promote purchases. Moreover, recently a substantial increase in sales of children's goods has been observed.

It should be noted that over two thirds of the respondents claimed using the services of foreign e-shops. There may be several reasons for this: a broader range of goods in the foreign e-shops, a better quality of the goods, differences in prices, etc. Neither higher costs of delivery, nor more complicated terms of payment scare consumers from purchasing in foreign e-shops, which may mean that the supply offered by Lithuanian e-shops still does not fully meet the needs of consumers. In response to the question about the types of e-shops, which Lithuania lacks, the respondents ranked e-shops selling holiday packages (18\%) as number one. The second highest ranking was the shortage of e-shops of clothing and footwear (16\%). 11\% of the respondents pointed out a shortage of shops of perfumes, cosmetics, another $11 \%$ of the respondents noted a lack of shops of leisure and sports items (Fig. 4). 7\% of the respondents pointed out the insufficient number of e-shops selling children's goods and airline tickets.

Such results of the survey clearly reflect the consumers' need for a wider range of goods compared to the current supply of Lithuanian e-shops.

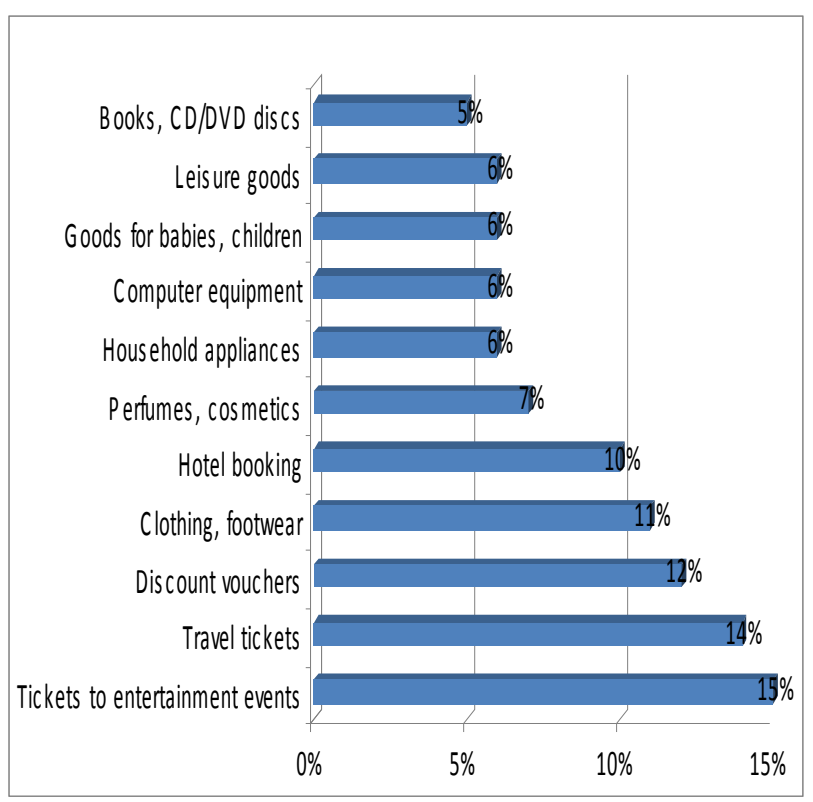

Fig. 3. Goods/services purchased online.
Almost all respondents intend to continue purchasing online also in the future; just 4\% replied that they were not certain whether they would purchase. None of the respondents stated that he/she would never purchase online again. $94 \%$ of the respondents, who purchased online, were satisfied with their purchase, which means that online purchases are a convenient way of purchasing.

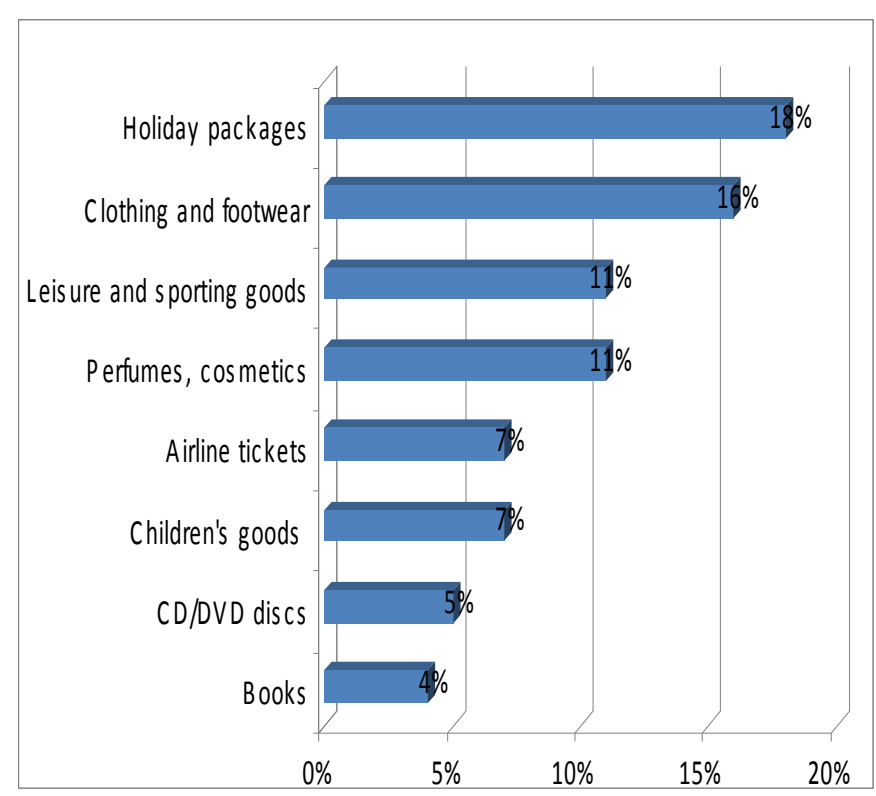

Fig. 4. Shortage of e-shops in Lithuania.

The respondents note that they are most often prompted to purchase online by favourable prices and a faster process of purchasing (Fig. 5). Other reasons worth mentioning include the possibility of purchasing without leaving home and at any time of the day, a broader range of products and the possibility to quickly obtain information.

In fact, these are the main advantages of e-commerce in respect of consumers. This means that consumers are not willing to go to shopping centres, wait in queues, etc.

The largest impact on the decision not to purchase online is exerted by several factors. Interestingly, buyers believe that the absence of the possibility to touch is the key reason preventing from purchasing over the Internet. Individuals are inclined to buy the items, which it is not necessary to touch (e.g., tickets, books, CD/DVD) or the products which are wellknown and regularly used, for instance, perfumes, cosmetics. 


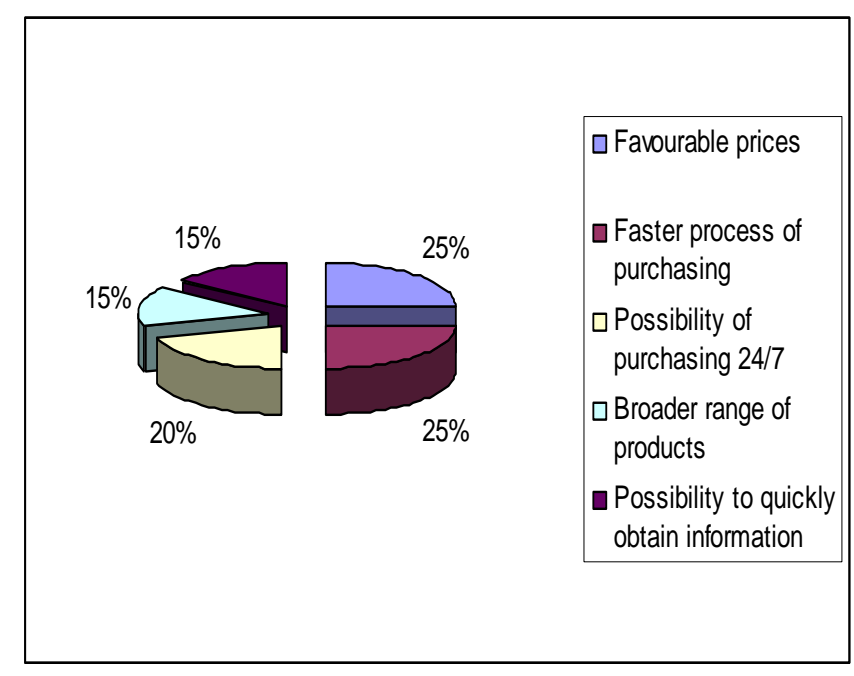

Fig. 5. Reasons for online purchasing.

According to the report on consumer complaints concerning e-commerce, which was elaborated by the European Consumer Centre Network, most claims were related to delivery of products and the quality of products themselves (http://www.ecc.lt). On the basis of this information, a study was carried out in order to determine delivery-related information provided by Lithuanian e-shops at their web-sites. As web-site rankings are hardly compiled, the TOP10 most popular e-shops were selected for the purpose of this research based on data of an international company "Alexa" ("Alexa Internet" is a California-based company belonging to Amazon.com and providing web traffic data). Out of 10 most popular (according to "Alexa") Lithuanian eshops, only 4 web-sites provide information about the time of delivery, and at other websites such information is not provided. Therefore, consumers are forced to contact the seller in order to obtain additional information, which may result in the determination to simply avoid purchasing online, because this circumstance requires spending additional time for clarification of information instead of saving time. An analysis of the manner of delivery shows that consumers are allowed to choose from 3 ways of delivery, i.e., delivery of a product by a courier, by mail, or simply by receiving a product at a traditional shop, or at other indicated product collection points. In terms of the price of delivery, it first and foremost depends on the method of delivery/collection of a product. It is possible to collect an ordered product free of charge. In this case, the product should be collected at the indicated collection points. Otherwise, delivery prices differ depending on a specific product, its size and weight.

\section{CONCLUSIONS}

In 2011, the share of individuals purchasing over the Internet in Lithuania accounted for $11 \%$ of the population, and Lithuania ranked $22^{\text {nd }}$ in the EU-27. In the business sector, only $33.2 \%$ of enterprises purchased products/services online and $24.7 \%$ sold products/services. It may be claimed that the opportunities offered by the Internet in the area of commerce still are insufficiently used.

A typical respondent in this research is aged 25-30 years, has a high school diploma and earns moderate income, uses the Internet daily and purchases online 6-7 times per year on average. $87 \%$ of the respondents purchase products over the Internet and $94 \%$ of the respondents, who purchased online, were satisfied with their goods. This means that online purchases are a convenient way of purchasing.

The most popular products for personal use are tickets to entertainment events (15\%), travel tickets (14\%) and discount vouchers (12\%). According to respondents' opinion, the most important reasons to purchase online are favourable prices and a faster process of purchasing. Other reasons worth mentioning include the possibility of purchasing without leaving home and at any time of the day, a broader range of products and the possibility to quickly obtain information.

The reasons why people do not buy on the Internet are considerable distrust of consumers and their feeling of insecurity when purchasing in a virtual environment (according to different studies, it accounts for 34-50\% of the respondents). The second most important reason preventing from purchasing over the Internet $(27-32 \%$ of the respondents) is the absence of a possibility to touch items. Therefore, people are more willing to purchase the items, which it is not necessary to touch (e.g., tickets, books, CD/DVD), or the items that are well-known to customers and used regularly, such as perfumes, cosmetics.

The existing e-shops in Lithuania do not sufficiently meet the needs of Lithuanian e-consumers, because in the opinion of the respondents, there is a shortage of e-shops offering holiday packages $(18 \%)$, clothing and footwear $(16 \%)$, perfume and cosmetics (11\%), leisure and sports items (11\%). Besides, $7 \%$ of the respondents pointed out that there is an insufficient number of e-shops selling children's goods and airline tickets. It reflects the consumers' need for a wider range of goods compared to the current supply of Lithuanian e-shops.

\section{REFERENCES}

[1] R. Aburukba, A. Wahaishi, H. Ghenniwa, W. Shen, "Privacy-based Computation Model in E-business", International Journal of Production Research vol. 47(17), 2009, pp. 4885-4906. http://dx.doi.org/10.1080/00207540902847421

[2] S. S. Alam, M. Y. Ali, M. F. M. Jani, „An Empirical Study of Factors Affecting Electronic Commerce Adoption among SMEs in Malaysia", Journal of Business Economics and Management, vol. 12 (2), 2011, pp.375-399. http://dx.doi.org/10.3846/16111699.2011.576749

[3] I. Andersone, E. Gaile-Sarkane, "Behavioral Differences in Consumer Purchasing Behavior Between Online And Traditional Shopping: Case Of Latvia". Economics \& Management: 2009. 14. p.345 -352. ISSN $1822-6515$

[4] I. Andersone, E. Gaile-Sarkane, "Influence of Factors on Consumer Behavior". In the 5th International Scientific Conference "Business and Management' 2008". 16-17 May 2008. Vilnius, Lithuania: selected papers. Vilnius: Technika. p.331 - 337. ISSN 2029-4441

[5] R. L Andrews, I. S. Currim, 2004. "Behavioural differences between consumers attracted to shopping online versus traditional supermarkets: implications for enterprise design and marketing strategy". Int. J. Internet Marketing and Advertising 1(1):38-61. http://dx.doi.org/10.1504/IJIMA.2004.003689

[6] S. J. Andriole, The 2nd Digital Revolution. IRM Press. 2005 http://dx.doi.org/10.4018/978-1-59140-801-7

[7] B. Canzer, E-business. Strategic Thinking and Practice. Houghton Mifflin Company. Boston, New York. 2003.

[8] D. Chapman and B. Sheehy, Smart Business. USA: Bang Printing. 2002

[9] V. Davidavičienè, R. Gatautis, N. Paliulis, R. Petrauskas, Elektroninis verslas. Vilnius: Technika. 2009. (E-business

[10] V. Davidavičienė and J. Tolvaišas, (2011) "Measuring quality of ecommerce web sites: case of Lithuania". Economics and Management. 16. $723-729$ p. 
[11] C. P. Deans, E-commerce and M-commerce Technologies. USA: Idea Group. 2004

[12] M. Draganov. "Consumer-based Market Segmentation in Bulgarian WEB space". Scientific Proceedings of Scientific-Technical Union of Mechanical Engineering, Scientific Engineering, Year XIX, Issue 2 (122), June 2011, IX International Conference „Management and Engineering'11“, JUNE 19-22, 2011Sozopol, ISSN 1313 - 7123. Volume II, 534-543.

[13] Ch. Dennis; B. Merrilees; Ch. Jayawardhena; L.T. Wright (2009) "Econsumer behaviour", European Journal of Marketing 43 (9/10): 11211139. http://dx.doi.org/10.1108/03090560910976393

[14] E. Gaile-Sarkane. "What Does The E-Customer Really Wants?" Economics \& Management: 2008. 13. p. 256-260.

[15] Global Consumer Behavior 2007. Ed. Chantal Ammi. ISTE Ltd, London. ISBN 978-1-905209-63-7.

[16] S. M. Hashemi, M. Razzazi, M. Teshnehlab. 2006. "Service Oriented Privacy Modeling in Enterprises with ISRUP E-Service Framework". Available from Internet: http://www.w3.org/2006/07/privacyws/papers/08-hashemi-isrup/

[17] T.K. Hui; D. Wan. 2007. "Factors affecting Internet shopping behaviour in Singapore: gender and educational issues"; International Journal of Consumer Studies 31, 310-316. http://dx.doi.org/10.1111/j.14706431.2006.00554.x

[18] K. Kolos; M. Gáti; T. Gyulavari. "E-Commerce Evolution In Hungary: An Investigation of Critical Success Factors". In Marketing Theory Challenges in Emerging Societies. Conference Proceedings. 2011. p.156 - 162. ISBN:978-973-640-681-2

[19] E. Y. Li, T. C. Du. Advances in Electronic Business. USA: Idea Group Publishing. 2005.

[20] 11 M. Norris and S. West, S. "eBusiness Essentials. Technology and Network Requirements for Mobile and Online Markets". John Willey \& Sons, Ltd. 2001.

[21] N. Paliulis, A. Pabedinskaitė, L. Šaulinskas. Elektroninis verslas: raida ir modeliai. Vilnius: Technika. 2007. (E-business: development and models)

[22] R. Plant. E-commerce: Formulation and Strategy. New Jersey: Prentice Hall. 2001.
[23] N. Park, J. Mezias, J. Song. "A Resource-based View of Strategic Alliances and Firm Value in the Electronic Marketplace", Journal of Management, vol. 30(1), 2004. pp. 7-27. http://dx.doi.org/10.1016/j.jm.2002.11.001

[24] M. Quayle. "Purchasing in Small Firms", European Journal of Purchasing \& Supply Management, vol. 8(3), 2002. pp. 151-159. http://dx.doi.org/10.1016/S0969-7012(02)00005-9

[25] G. Stasiūnas. New e-shop marketing plan. Bachelor thesis. Supervisor A. Pabedinskaitè. 2012. (in Lithuanian)

[26] D. Šceulovs; E. Gaile-Sarkane. "Identification of Factors affecting Consumer Habits in the E-Environment". In the 7th International Scientific Conference "Business and Management' 2010". 13-14 May 2010. Vilnius, Lithuania: selected papers. Vilnius: Technika. p.965- 970. ISSN 2029-4441

[27] A. Pabedinskaite; A., V. Sliazaite (2011) „Consumers“ Behaviour Model in Traditional and E-Commerce". Scientific Proceedings of ScientificTechnical Union of Mechanical Engineering. Year XIX, Issue 2(122), June 2011. IX International Conference „Management and Engineering '11" June 19-22. Sozopol, Bulgaria. Volume II, p. 473-482.

[28] E. Turban, D. King; J. Lee; M. Warkentin; H. M. Chung. Electronic Commerce. Prentice Hall. 2002.

[29] L.H. Wen and J. Hong. "The Effects of E-business on the Performance of Strategic Alliances", Total Quality Management, vol. 21(7), 2010. pp. 707-724. http://dx.doi.org/10.1080/14783363.2010.483085

[30] www.stat.gov.lt

Arnoldina Pabedinskaite received a PhD Degree in Economics from the Scientific Institute of Systematic Research (Moscow, 1985). The author also received a Doctoral Degree of Social Science (Management) from Vilnius Gediminas Technical University in 1994.

She is presently an Associate Professor at the Department of Business Economics, Mykolas Romeris University, Vilnius (Lithuania).

She has over 120 publications and her research interests include emarketing, knowledge management, application of quantitative methods to business, economics and management.

\section{Arnoldina Pabedinskaite. Elektroniskās komercijas attīstība Lietuvā}

Veiksmīga biznesa att̄̄stība mūsdienās nav iedomājama bez interneta un citām informācijas un komunikācijas tehnologijiām. Mūsdienīgas informācijas un komunikācijas tehnologijas rada iespēju paplašināt esošos transnacionālos tirgus un iziet jaunos tirgos. 2011. gadā Lietuva starp 27 ES valstīm bija 22 . vietā pēc elektroniskās komercijas apjoma, kas sastāda 11\% no kopējās populācijas, savukārt vidēji Eiropāa šis rādītājs ir 34\%. Pircēju skaits internetā pastāvīgi aug, bet ekomercijas attīstības līmenis Lietuvā būtiski atpaliek no Eiropas vidējā rādītāja. Raksta mērḳis ir veikt e-komercijas attīstības līmeņa analīzi un identificêt patērētāju uzvedības īpatnības internetā. Pētījums parādīja, ka 33,2\% uzṇēmumu iegādājas preces un pakalpojumus un 24,7\% uzṇēmumu pārdod savas preces/ pakalpojumus, izmantojot internetu. Populārākais produkts, kuru pērk personiskai lietošanai internetā, ir koncertu un izrāžu biḷetes. Esošie interneta veikali nepietiekami apmierina patēēetāju vajadzības, tāpēc ir nepieciešams paplašināt preču un pakalpojumu sortimentu.

\section{Арнольдина Пабединскайте. Развитие электронной коммерции в Литве}

Успешное развитие бизнеса в настоящее время невозможно без использования интернета и других информационно коммуникационных технологий (ИКТ). Современные ИКТ представляют широкие возможности расширения имеющихся транснациональных рынков и вхождения в новые. В 2011 году Литва была на 22-ом месте по обьему электронной коммерции среди 27 стран Евросоюза. Объем эл-коммерции составил $11 \%$ от общей популяции, в то время как в среднем по Евросоюзу он равен 34\%. Число покупателей в Интернете постоянно растет, однако уровень развития элкоммерции в Литве существенно отстает от среднего по Евросоюзу. Цель данной статьи проанализировать уровень развития эл-коммерции в Литве и идентифицировать некоторые особенности поведения потребителей в Итернете. Исследование показало, что $33.2 \%$ предприятий покупают продукты или услуги по Интернету и 24.7 \% продают свои продукты/услуги. Наиболее популярными продуктами, покупаемыми для персонального использования, являются билеты на концерты и спектакли. Существующие электронные магазины недостаточно удовлетворяют потребности покупателей, поэтому необходимо расширять ассортимент продаваемых продуктов и услуг. 